Supplement of Biogeosciences, 11, 2531-2542, 2014

http://www.biogeosciences.net/bg-11-2531-2014/

doi:10.5194/bg-11-2531-2014-supplement

(C) Author(s) 2014. CC Attribution 3.0 License.

(c) (i)

Supplement of

\title{
Lytic viral infection of bacterioplankton in deep waters of the western Pacific Ocean
}

\section{Y. Li et al.}

Correspondence to: R. Zhang (ruizhang@xmu.edu.cn) and N. Jiao (jiao@xmu.edu.cn) 
Table S1. Location and environmental features of each sampling station in the western Pacific Ocean. -, no data.

\begin{tabular}{|c|c|c|c|c|c|c|c|c|c|c|c|c|c|c|}
\hline \multirow[t]{2}{*}{ Station } & \multirow[t]{2}{*}{$\begin{array}{l}\text { Longi } \\
\left({ }^{\circ} \mathbf{E}\right)\end{array}$} & \multirow[t]{2}{*}{$\begin{array}{l}\text { Lati } \\
\left({ }^{\circ} \mathrm{N}\right)\end{array}$} & \multicolumn{4}{|c|}{$\begin{array}{c}\text { Temperature } \\
\left({ }^{\circ} \mathbf{C}\right)\end{array}$} & \multicolumn{4}{|c|}{$\begin{array}{c}\text { Salinity } \\
\text { (psu) }\end{array}$} & \multicolumn{4}{|c|}{$\begin{array}{l}\mathrm{NH}_{4}^{+} \\
(\mu \mathrm{M})\end{array}$} \\
\hline & & & $0 \mathrm{~m}$ & $200 \mathrm{~m}$ & $1000 \mathrm{~m}$ & $2000 \mathrm{~m}$ & $0 \mathrm{~m}$ & $200 \mathrm{~m}$ & $1000 \mathrm{~m}$ & $2000 \mathrm{~m}$ & $0 \mathrm{~m}$ & $200 \mathrm{~m}$ & $1000 \mathrm{~m}$ & $2000 \mathrm{~m}$ \\
\hline $\mathrm{N}-1$ & 122.398 & 17.590 & 28.01 & 18.38 & 3.76 & 2.08 & 32.17 & 34.79 & 34.49 & 34.64 & 1.01 & 0.61 & 0.51 & 0.32 \\
\hline $\mathrm{N}-2$ & 123.459 & 17.989 & 27.76 & 19.58 & 3.61 & 2.07 & 32.48 & 34.81 & 34.51 & 34.64 & 0.43 & 0.75 & 0.51 & 0.31 \\
\hline $\mathrm{N}-3$ & 125.991 & 18.023 & 28.26 & 19.83 & 3.87 & 2.09 & 34.06 & 34.85 & 34.49 & 34.63 & 0.13 & 1.03 & 0.25 & 0.45 \\
\hline N-4/ E-1 & 129.598 & 17.599 & 28.78 & 26.69 & 3.91 & 1.68 & 33.32 & 34.87 & 34.50 & 34.67 & 1.04 & 0.53 & 0.36 & - \\
\hline E-2 & 129.990 & 14.916 & 29.04 & 20.35 & 4.19 & 2.03 & 33.68 & 34.91 & 34.54 & 34.64 & 0.22 & 0.40 & 0.50 & 0.37 \\
\hline E-3 & 129.972 & 11.975 & 29.52 & 17.76 & 4.08 & 2.27 & 33.86 & 34.73 & 34.56 & 34.63 & 0.53 & 0.57 & 0.63 & 0.20 \\
\hline E-4 & 129.989 & 9.003 & 29.71 & 15.70 & 4.76 & 2.22 & 33.63 & 34.61 & 34.55 & 34.64 & 0.29 & 0.58 & 0.60 & 0.33 \\
\hline E-5 & 129.983 & 7.999 & 29.75 & 12.43 & 4.91 & 2.99 & 33.82 & 34.48 & 34.55 & 34.60 & 0.31 & 0.29 & 0.41 & 0.36 \\
\hline E-6 & 129.990 & 6.503 & 29.70 & 12.97 & 4.78 & 2.24 & 33.72 & 34.47 & 34.55 & 34.64 & 0.98 & 0.49 & 1.15 & 0.07 \\
\hline E-7 & 129.994 & 3.003 & 29.89 & 20.17 & 4.63 & 2.27 & 34.60 & 34.90 & 34.56 & 34.64 & 0.72 & 0.20 & 1.09 & 0.99 \\
\hline
\end{tabular}




\begin{tabular}{|c|c|c|c|c|c|c|c|c|c|c|c|c|c|c|c|c|}
\hline \multirow[t]{2}{*}{ Station } & \multicolumn{4}{|c|}{$\begin{array}{l}\mathrm{NO}_{2}^{-} \\
(\mu \mathrm{M})\end{array}$} & \multicolumn{4}{|c|}{$\begin{array}{c}\mathrm{NO}_{3}^{-}+\mathrm{NO}_{2}^{-} \\
(\mu \mathrm{M})\end{array}$} & \multicolumn{4}{|c|}{$\begin{array}{l}\mathrm{SiO}_{3}^{2-} \\
(\mu \mathrm{M})\end{array}$} & \multicolumn{4}{|c|}{$\begin{array}{l}\mathrm{PO}_{4}{ }^{3-} \\
(\mu \mathrm{M})\end{array}$} \\
\hline & $0 \mathrm{~m}$ & $200 \mathrm{~m}$ & $1000 \mathrm{~m}$ & $2000 \mathrm{~m}$ & $0 \mathrm{~m}$ & $200 \mathrm{~m}$ & $1000 \mathrm{~m}$ & $2000 \mathrm{~m}$ & $0 \mathrm{~m}$ & $200 \mathrm{~m}$ & $1000 \mathrm{~m}$ & $2000 \mathrm{~m}$ & $0 \mathrm{~m}$ & $200 \mathrm{~m}$ & $1000 \mathrm{~m}$ & $2000 \mathrm{~m}$ \\
\hline N-1 & 0.03 & 0.04 & 0.04 & 0.04 & & 1.27 & 27.34 & 23.61 & 0.27 & 1.73 & 63.74 & 77.27 & 0.09 & 0.04 & 1.60 & 1.86 \\
\hline $\mathrm{N}-2$ & 0.04 & 0.11 & 0.05 & 0.09 & 0.38 & 2.76 & 31.63 & 28.96 & 0.09 & 1.76 & 72.77 & 74.97 & 0.00 & 0.00 & 1.13 & 1.34 \\
\hline $\mathrm{N}-3$ & 0.03 & 0.10 & 0.09 & 0.18 & 0.00 & 5.79 & 34.21 & 19.67 & 0.22 & 0.97 & 66.17 & 76.61 & 0.07 & 0.60 & 1.76 & 1.12 \\
\hline $\mathrm{N}-4 / \mathrm{E}-1$ & 0.00 & 0.06 & 0.26 & - & 0.20 & 3.12 & 14.85 & - & 0.27 & 0.56 & 73.51 & - & 0.06 & 0.00 & 1.49 & - \\
\hline E-2 & 0.03 & 0.06 & 0.05 & 0.04 & 0.00 & 8.20 & 26.21 & 27.67 & 0.05 & 1.35 & 61.48 & 78.66 & 0.05 & 0.35 & 1.37 & 2.01 \\
\hline E-3 & 0.06 & 0.07 & 0.04 & 0.00 & 0.12 & 8.07 & 25.60 & 20.87 & 0.31 & 4.78 & 63.51 & 74.06 & 0.13 & 0.35 & 1.09 & 1.06 \\
\hline E-4 & 0.01 & 0.04 & 0.13 & 0.08 & 0.88 & 10.73 & 20.62 & 14.38 & 0.35 & 8.76 & 53.81 & 73.98 & 0.07 & 0.07 & 0.78 & 1.16 \\
\hline E-5 & 0.08 & 0.07 & 0.02 & 0.08 & 0.93 & 15.58 & 28.78 & 30.21 & 0.00 & 9.80 & 52.86 & 71.12 & 0.00 & 0.91 & 1.63 & 2.17 \\
\hline E-6 & 0.02 & 0.02 & 0.04 & 0.05 & 0.00 & 1.66 & 28.78 & 15.98 & 0.33 & 10.50 & 55.92 & 74.19 & 0.18 & 0.95 & 1.13 & 1.04 \\
\hline E-7 & 0.04 & 0.04 & 0.04 & 0.08 & 0.35 & 3.45 & 24.19 & 20.97 & 0.37 & 4.03 & 54.01 & 68.73 & 0.04 & 0.45 & 1.40 & 1.03 \\
\hline
\end{tabular}

